[Raskauskas, J., \& Prochnow, J. E. (2007). Text-Bullying in New Zealand: A Mobile Twist on Traditional Bullying. New Zealand Annual Review of Education, 16, 89-104]

\section{Text-Bullying in New Zealand: A Mobile Twist on Traditional Bullying}

\author{
JULIANA RASKAUSKAS AND JANE E. PROCHNOW
}

\section{Abstract:}

Unfortunately, negative peer interactions such as bullying are a common occurrence in schools across New Zealand. New Zealand students reported higher than average rates of bullying in international studies such as the Progress in International Reading Literacy Study (PIRLS). Research within New Zealand has indicated that as many as $75 \%$ of students reported being bullied at least once a year (Adair, 1999). In addition to bullying in schools, students today may also face bullying through personal technologies such as mobile phones. This article discusses the nature and prevalence of text-message bullying through emerging research involving secondary school students in New Zealand.

$\mathrm{B}$

ullying has been well documented as a pervasive phenomenon in schools, which can have many damaging effects on students (Olweus, 2001; Sullivan, 2000). Traditionally, bullying is said to occur when a child is the target of any behaviour that is: (a) harmful or done with intent to harm; (b) repeated or occurs over time; and (c) characterized by an imbalance of power such that the victim does not feel he or she can stop the interaction. When students are of the same strength or behaviours are done in a playful manner the interactions are not considered bullying (Espelage \& Swearer, 2003; Olweus, 2001).

Bullying is a major concern for educators and policy makers because being bullied negatively affects the academic performance of many children and can lead to school avoidance among other students (Buhs \& Ladd, 2001; Furlong, Sharma, \& Rhee, 2000). Being bullied by peers has also been found to lead to lower psychological well-being for bullied children, contributing to the development of psychological distress such as heightened anxiety, depression, and a lower sense of self-worth
(Austin \& Joseph, 1996; Grills \& Ollendick, 2002; O'Moore \& Kirkham, 2001). Research consistently has found that the negative academic and emotional effects of bullying on victims occur soon after being bullied and are maintained over time (Bond, Carlin, Thomas, Rubin \& Patton, 2001; Olweus, 2001).

Those who bully others also suffer short-term and long-term effects. Bullies may suffer peer rejection, academic failure, and/or low self-esteem. They often lack empathy and report more acceptance of aggression and violence in relationships than non-bullies (Espelage \& Swearer, 2003; Sullivan, 2000). Children who bully are also four times more likely to have criminal convictions in adulthood than their non-bullying peers (Olweus, 1993, 2001). Quite possibly, the relationship of bullying to later delinquency and offending is due to the fact that, without intervention, bullies learn that using aggression is an acceptable means of forcing compliance.

The purpose of this article is to examine bullying in New Zealand. Research on prevalence and forms are reviewed along with our recent analysis of the Progress in International Reading Literacy Study (PIRLS) international comparison data set. The newest bullying threat-bullying via text-messages - is also explored. The nature and prevalence of text-message bullying is discussed through emerging research involving secondary school students in New Zealand.

\section{Bullying in New Zealand}

Within New Zealand three studies have indicated that bullying is a problem for many students. In a survey of 960 students aged 7 to 16 years, Cram, Doherty, and Pocock (1995) found that $75 \%$ of girls and $77 \%$ of boys reported having experienced bullying at some point in school. Approximately $50 \%$ of the boys and $34 \%$ of the girls reported bullying others, such that one third of the students were both bullies and victims. When Maxwell and Carroll-Lind (1997) examined bullying, defined as having been punched, kicked, beaten, or hit, over half of the 10-13 year old respondents indicated that they had been bullied in the previous nine months.

Adair, Dixon, Moore and Sutherland (2000) surveyed 2,066 students in Years 9 to 13 regarding their experiences of and participation in bullying. When bullying was left to the students' own definition over half of the students reported having been bullied. A further $44 \%$ reported that they had bullied others. Students participating in this survey also responded to a list of hurtful behaviours they had 
experienced at school. Analyses based on responses to the listed behaviours suggested that $75 \%$ of the students indicated they had experienced at least one of the bullying behaviours in the previous year.

\section{International Comparison}

The above studies indicated that bullying behaviours were present in the schools of New Zealand at a relatively high level. However, it is unclear how these rates compare with rates of bullying in other countries. Differences in understanding what constitutes bullying across countries and how those data are collected can make direct international comparisons difficult. Recently the International Association for the Evaluation of Educational Achievement (IEA) conducted an international investigation known as the Progress in International Reading Literacy Study (PIRLS). New Zealand was one of the 35 countries which took part in this literacy evaluation and assessment. Data were collected from school principals, teachers, parents and students regarding school structure, perceptions of school safety, teaching practices, student attitudes toward reading, student behaviours, parental attitudes toward reading, and both home and school resources. Participating countries went through a rigorous iterative process of sampling and data collection to insure standards were met to prevent bias in sampling and assessment to facilitate international comparisons. These data included items on bullying that allow comparisons to be made between New Zealand and other countries.

In New Zealand, approximately 2,500 Year 5 students from 156 schools participated in the PIRLS (Ministry of Education, 2003). The assessment instrument included three questions regarding students' personal experiences with bullying, theft and being hit or hurt. Specifically of interest for this study was the question regarding bullying: Have you been bullied by another student in the past month? (Mullis, Martin, Gonzalez \& Kennedy, 2003). Students responded either "yes" or "no" to this item. This item was included in the assessment by 33 of the 35 countries (England and Germany did not).

Results indicated that New Zealand ranked tenth in a descending ranking of countries by percentage of students bullied in the past month, with $38 \%$ of students reporting being bullied. This number was above the international average (33\%). The highest percentage of students reported bullying in Israel $(66 \%)$ and Argentina $(63 \%)$ with the lowest percentages reported in Bulgaria (13\%) and Sweden (12\%).
Canada $(31 \%)$ ranked 16th and the United States $(25 \%)$ was ranked 24th.

The PIRLS data were collected primarily to examine questions related to literacy and reading achievement. Previous research has investigated the relations of social class, gender, student behaviour and schools' early literacy teaching practices relative to reading achievement in the New Zealand PIRLS data (Nash, 2004; Prochnow, 2004; Tunmer \& Chapman, 2004). It was also of interest, therefore, to question whether New Zealand's reported high levels of bullying were related to the reading and literacy achievement of students. On the basis of statistical t-test analyses, we found that the mean overall academic achievement of students responding "No" to experiencing bullying was significantly higher than the mean of students who responded "Yes" for each of the bullying behaviours (Prochnow \& Raskauskas, 2006).

Bullying was also related to school characteristics. When schools with more than 19 participating students were examined by quartiles based on the amount of student bullying reported ( 47 schools with 1,231 students), we found a significant relationship between bullying in the schools and economic disadvantage in the home (measured by school decile or responses by school principals to questions regarding the percentage of students in the school from economically disadvantaged homes). Lower levels of bullying were associated with higher overall levels of reading achievement by class/school mean. In other words, students in "low bullying" schools have significantly higher achievement as measured by the PIRLS literacy measures. The students in the quartile of schools showing the lowest levels of bullying also had the most positive attitudes towards reading.

Although t-tests and regression analyses are not causal analyses, these findings do demonstrate significant relationships between the presence or experience of bullying, literacy achievement and home/school economic indicators. Given that schools with reported lower levels of bullying behaviours had higher literacy achievement, students with more connection to the schools and safer learning environments, the presence of bullying seems to characterize the school environment affecting both academic achievement and social interaction.

This research indicated that bullying is an area of concern for schools. However, as the PIRLS research is limited to Year 5 students (aged 9-10 years) these comparisons need to be conducted with older students as well. This research was also confined to student self-reports 
of general bullying experiences. It must be noted that bullying can take many different forms, and the prevalence can differ across these forms.

\section{Forms of Bullying}

Three main forms of bullying have been defined in the literature: physical, verbal, and relational aggression (Sullivan, 2000). Physical bullying occurs when one or more students hit, kick, push, or shove a child, when the action is done in an unfriendly manner, and when the two students are not of the same strength or power. Verbal bullying is said to occur when children repeatedly tease, say mean and hurtful things, or call children names (Olweus, 2001; O'Moore \& Kirkham, 2001). Physical and verbal bullying are most prevalent in child hood, but have been shown to continue into adolescence (Sullivan, 2000; Whitney \& Smith, 1993)

The third type of bullying, referred to as relational aggression (Crick \& Nelson, 2002) includes both physical and verbal actions, but is qualified by the psychological components of active exclusion and manipulation of relationships. Victims of relational aggression are youths whose peers use their relationships as a means to control or harm them. Exclusion and spreading gossip about someone are the primary forms of relational aggression (Crick \& Nelson, 2002; Sullivan, 2000). This has been described as the most harmful form of bullying because it deprives students of important social relationships and experiences (Coleman \& Byrd, 2003). Relational aggression is most common during intermediate and early secondary school years (Crick \& Nelson, 2002).

In a study of 1,370 New Zealand students, aged 7-18 years, Carroll-Lind and Kearney found that while $63 \%$ of their sample reported one or more experiences of bullying during the current school year, their experiences differed by form of bullying. Forty-one percent of students reported experiencing physical bullying such as hitting, kicking, or shoving, 46\% reported experiencing mean name calling, 33\% reported exclusion or being purposely left out of things, and $34 \%$ reported having untrue or mean gossip spread about them during that school year. These percentages add up to more than $100 \%$, which indicates that some students experienced more than one form of bullying during the school year (2004, p. 20).

This research project also reported that a small percentage of students had been bullied via text-messages and email. Some have heralded electronic bullying by text-messages or email as a new form of bullying. However, bullying by these technologies appears to utilize familiar forms of bullying in novel ways. For example, spreading gossip, rumours, secrets, and facilitating exclusion are forms of relational aggression. Sending insults, threats, and mean names are forms of verbal bullying. Bullying via text-messages makes creative use of these relational and verbal forms by delivering them through a new medium. However, to date, little research has been conducted examining bullying via text-messages and the effects it might have on students.

\section{Nature and Prevalence of Text-Bullying}

Access to a mobile phone is recognized as a vital necessity among adolescents. Many adolescents describe their mobile phone as their most prized possession $(\mathrm{NCH}, 2005) .{ }^{1}$ A recent study of 1,528 adolescents 12-19 years of age in New Zealand in 2005 indicated that $73 \%$ of them owned a mobile phone and, of those who did not have their own mobile phone, $69 \%$ said they had access to and used someone else's mobile phone (Internet Safety Group, 2005, p. 2). However, the increased dependence on mobile phones has given rise to bullying using text-messages. A 2005 survey of the "text-generation" conducted in Auckland found that $23 \%$ had received text-messages that they considered offensive, abusive, or threatening (Internet Safety Group, 2005 , p. 3). This emerging form of bullying by mobile phone textmessages is called "text-bullying". Text-bullying has been defined as a means of bullying in which adolescents use text-messages to threaten, harass, and/or intimidate a peer. The perpetrators of text-bullying send text-messages to spread rumours or secrets, call the victim mean names, or organize the exclusion of the victim from social activities.

Prevalence rates for text-bullying are preliminary, as research is just beginning to report on student experiences. In a study involving one secondary school in New Zealand, $12 \%$ of students $13-18$ years of age reported being text-bullied while $47 \%$ knew personally of someone who had been text-bullied in the current school year (Raskauskas, Carroll-Lind, \& Kearney, 2005, p. 8). Similarly, in a Canadian sample of students, $25 \%$ of students 13-15 years of age had been harassed through their mobile phones (Beran \& Li, 2005, p. 269). In the United Kingdom, $14 \%$ of students aged between $12-16$ years reported being victims of text-bullying and $11 \%$ admitted sending bullying texts to someone else (NCH, 2005, p. 3). A small study in the United States, with a convenience sample of adolescents 13-18 years of age, reported that $32 \%$ of the respondents had been text-bullied (Raskauskas \& Stoltz, 2007, p. 567). 
These rates vary and seem dependent on the nature of the convenience samples from which they are drawn. Larger studies are needed to assess prevalence rates which can be generalized.

The limited research indicated that text-bullying may victimize the same students who experience traditional bullying, in which case the risk of negative effects may be additive. Beran and Li $(2005$, p. 271) reported a relationship between general cyber-bullying and traditional bullying among Canadian youth, such that $64 \%$ of cyber-victims were also victims of traditional bullying. In support of this, research in one New Zealand high school revealed that $70 \%$ of the text-victims were also victims of verbal and relational bullying at school (Raskauskas, Carroll-Lind, \& Kearney, 2005, p. 9). Research in the United States examining several forms of electronic bullying also found a relationship between text-bullying and both internet bullying and verbal bullying (Raskauskas \& Stoltz, in press).

The effects of text-bullying on student development and well-being are yet to be fully examined. Text-bullying may pose a greater threat to healthy social and emotional development than traditional bullying because of the nature of the relationship between the bully and victim. When using text-bullying the bullies are removed from their victims and the impact of their actions (Smith \& Williams, 2004). Consequently, students may feel free to say things by text that they would never say in face-to-face interactions. This dialogue can lead to faster escalation of text-bullying than traditional bullying because it is easier for victims to react immediately to harassing texts. Escalation is most likely to occur when the victims respond with hostility.

Finally, text-bullying may pose more of a threat to psychological health than traditional bullying because it transcends school grounds. As reported by the Internet Safety Group (2005), almost $60 \%$ of adolescents slept with their cell-phones every night. Cell-phones have been described as "an adolescent's most treasured possession" (NCH, 2005 , p. 2). Adolescents tend to keep cell-phones with them at all times, which allows text-bullies to have 24 hour access to their victims. With this access text-bullying victims are not safe from bullying even in their own homes. In support of this, students reported anxiety related to the threat of electronic bullying, including text-bullying, occurring after school (Raskauskas \& Stoltz, 2007, p. 569). Further, victims of cyber-harassment, including mobile phones, were more likely toindicate feeling angry, sad and hurt as a result of their experiences (Beran \& $\mathrm{Li}$, 2005).

\section{Emerging Research in Text-Bullying}

Recent research undertaken to examine text-bullying and associated effects in New Zealand investigated the relationship of text-bullying to symptoms of depression. The following hypotheses were tested:

1. Text-bullying will be associated with symptoms of depression.

2. Text-bullying will be associated with more symptoms of depression than traditional bullying.

In 2006, 1,153 adolescents, 11-18 years of age in New Zealand schools, completed surveys regarding their use of mobile phones, text-messaging and internet bullying, as well as traditional and depressive symptoms. Students from two secondary schools participated, including a co-educational school from the North Island $(\mathrm{N}=527$, decile 8$)$ and an all-girls school from the South Island $(\mathrm{N}=625$, decile 5$)$. Respondents identified themselves as Pakeha/New Zealand European (78\%), Maori $(10 \%)$, Pacific Islander (2\%), Asian $(2 \%)$ and Other $(8 \%)$

While teachers administered the surveys at the end of form class meetings, non-participating students engaged in alternative activities. Anonymous surveys were used to gather information from students. They included the following sections:

Demographics: Students self-reported on gender, age, year in school, ethnicity and parents' occupations. Students also answered items on mobile phone ownership, capabilities, and activities they engage in with their phone (i.e., I have used text-messages in a fight with a friend).

Text-bullying: A measure of text-bullying was developed for this research. Sixteen items asked about text-bullying experiences. Whether or not students were victims of text-bullying was assessed by one item "This year have you received harassing, threatening, or offensive text-messages?" The 475 students who answered "yes" were classified as text-victims. Students also answered how often this had occurred, where it occurred, whether they reported their experiences, and the nature of the bullying.

Traditional Bullying was assessed by four items similar to Ladd and Kochenderfer's (1996) measure. Students self-reported the extent to which they had experienced four types of bullying: physical (hitting, kicking, etc.), verbal (mean name calling), exclusion (being left out on purpose), and gossip (having mean gossip spread). Students were asked to respond for bullying experienced in the current school year. Each 
item was rated on a 5-point scale: (1) never, (2) only once or twice, (3) occasionally, (4) about once a month, and (5) once a week or more. Scores were averaged across the four items. For this analysis, dichotomous scores for traditional victimization were assigned. Students who had an average score of 2.5 or above, numbering 736, were classified as traditional victims.

Depressive Symptoms: Six items from the CES-D (developed by Radloff, 1977 , in order to assess depressive symptoms in the general population) were used to assess depressive symptoms. Students responded to how often they had felt depressive symptoms in the past week. Items were scored from 0 (rarely or none of the time) to 3 (most or all of the time). A mean was constructed for each student as the measure of depressive symptoms $(\mathrm{M}=0.97, \mathrm{SD}=0.56)$.

Students were provided with information on the NetSafe Text-bullying Hotline (0800 NETSAFE) at the end of their survey.

Analyses of these data showed that in total $41 \%$ of the respondents reported having been text-bullied; of these, $53 \%$ had experienced text-bullying as a one-off situation in 2006, and only $14 \%$ had experienced more persistent bullying ( 3 or more separate events). Differences occurred in terms of the gender composition of the participating schools: $52 \%$ of students were text-victims at the all-female school (27\% persistent victims), while $29 \%$ of students were text-victims at the co-educational school (14\% persistent victims). In the entire sample, most victims of text-bullying knew who was bullying them $(85 \%)$ and $52 \%$ of victims reported that it was someone from their school. The majority of bullying occurred outside of school around town $(38 \%)$ or at home $(83 \%)$ while only $28 \%$ of incidents occurred at school

These results support Hypothesis 1. Text-bullying was positively related to the incidence of depressive symptoms. ${ }^{2}$

Hypothesis 2 was also partially sustained. Students suffering text-bullying as well as traditional bullying were significantly more likely to suffer depressive symptoms. But there were no significant differences in depressive symptoms between those suffering from just one form of bullying, and the number of such symptoms was significantly lower. ${ }^{3}$ This relationship is illustrated in the box plot in Figure 1, where the mean score is indicated by the dark horizontal line, the "box" represents the inter-quartile range containing 50\% of the scores, and the "whiskers" show the total range of scores.

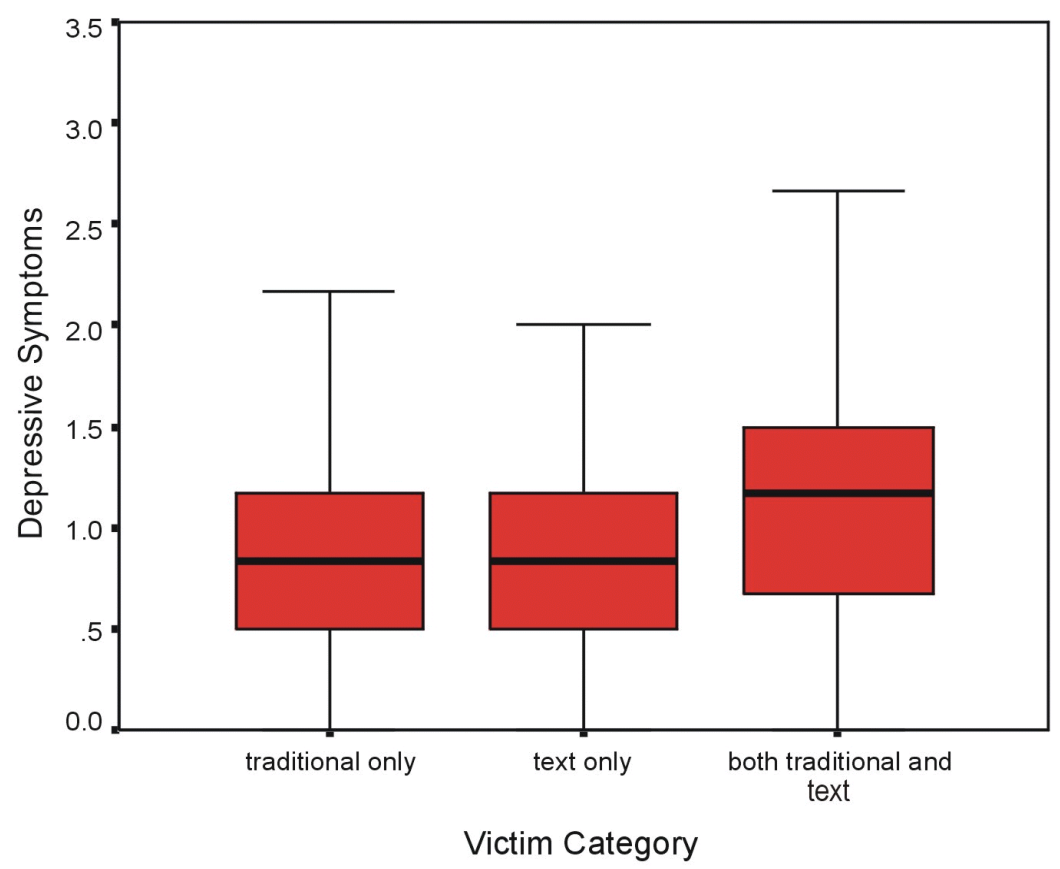

Figure 1 Comparison of means of traditional and text-bullying victims on depressive symptoms.

The fact that students knew who their bullies were has implications for reporting bullying. Students should be encouraged to report text-message bullying to school authorities. The overlap with traditional bullying may indicate that the same people are bullying across both media. This supports findings by Raskauskas and Stoltz (in press) that cyber-bullies and traditional bullies were usually the same people.

This research also indicated that there were negative effects to being text-bullied. While text-bullying was not found to be more closely related to depressive symptoms than traditional bullying, students who experienced both forms of bullying at the same time reported significantly more symptoms of depression. This implies a need for intervention with victims of text-message and traditional bullying.

It is important to note the limitations of this study. Primarily self-report data were used for all forms of victimization. A single item was used to identify victims of each form of bullying (text-bullying, physical, verbal, gossip, exclusion). These analyses are correlational only, 
and causality cannot be inferred. The relationships may be interpreted in both directions. For example, it may equally be possible that being depressed may make children more at risk of experiencing both text-bullying and traditional bullying. Finally, since a large proportion of text-victims were also victims of traditional bullying it is unclear if the rise in depressive symptoms is due to text-bullying, traditional bullying, or a combination of both. Certainly the unrelenting nature of text-bullying could increase a student's vulnerability, block access to support, or preclude a pause in which to gain resilience. However, the fact that students who experienced both forms of bullying had significantly higher reports of depressive symptoms than victims of traditional bullying alone indicates that text-bullying may make a unique contribution to the psychological distress of students. Future research is needed to examine these relationships further

Despite these limitations, these findings do provide needed information on text-bullying and associated outcomes among early adolescents. This research provides a necessary first step in examining the overlap between text-bullying and traditional bullying at school.

\section{Discussion}

Some preliminary suggestions for intervention and prevention can be drawn from the existing literature and research reported above.

\section{Be aware of bullying by text-messages}

Adults, and young people, may require education about the potential harm associated with mobile phone harassment. Educating adults who have contact with young people about the significance of this form of harassment is important, so they can offer an empathetic ear should such a situation ever be disclosed to them. Equally, educating young people about the potential significance of such victimization is important to validate their feelings, help prevent them from choosing to text-bully another person, and provide support to a friend or peer should an instance be disclosed to them.

Parental supervision of mobile phone use is difficult. Adolescents describe cell phones as the most direct and private way to communicate without family intervention (Schiano et al., 2002). Since mobile phones are a private communication technology, parents are often unaware of who their children are communicating with and the nature of those communications. Perhaps parents need to be more involved in their adolescent's use of mobile phones. Open communication and interest in mobile phone activities are key to parental involvement.

\section{Intervention in schools}

School is where most adolescents spend a large part of their time, so schools may be the best place to begin intervention efforts. The large overlap between bullying at school and by text-messages may mean that school may be where bullying starts; text-messages are then used to continue bullying outside of school hours. The overlap between traditional and electronic bullying is important because it means that some students are facing bullying both at school and outside school. We would recommend that the current bullying prevention curriculum be expanded to include text-bullying information, along with strategies to prevent or reduce its impact. Some activities that school can use include the following:

- Educating the school community (i.e., students, staff, parents and caregivers) about the significance, context, and potential problems associated with text-bullying.

- The website "Be Web Aware" <www.bewebaware.ca> has suggested actions for educators and students faced with text-bullying:

- Guard your contact information - don't give people your cell phone number.

- Never reply to harassing messages, particularly with hostility, as this will increase the harassment loop.

- Save harassing messages. Most cell phone providers have appropriate-use policies that restrict users from harassing others.

- Speak out when you see someone harassing others on-line or via cell phones. Most adolescents respond better to criticism from peers than from adults.

- Banning mobile phones at school may make students less likely to report text-bullying. One study found that $29 \%$ of adolescents used their mobile phone at least once during the school day when they were not allowed (Internet Safety Group, 2005). This study found that many students did not report their bullying because they did not want to get in trouble for having their mobile phones at school.

- Connecting text-message bullying to traditional bullying in existing intervention programmes may also help to validate the feelings of 
victims. Many youths do not recognize text-message harassment as bullying (Raskauskas \& Stoltz, 2007)

Vodafone and the Netsafe organization have launched a campaign to stamp out text-bullying among school students. They have developed brochures and posters about how to handle text-bullying and have distributed them to schools. Their materials encourage students to call the Netsafe text-bullying hotline manned by experienced staff. Students should be encouraged to report text-bullying to their school and to mobile phone providers.

\section{Future Directions}

The seriousness of the threat of text-bullying and its additive effects on traditional bullying demonstrate a need for future research in this area. Such research should focus on the effectiveness of prevention and intervention efforts.

\section{Notes}

1. NCH was founded in 1869 , and originally known as the National Children's Home, a name which it carried for many years. It is now simply known as NCH, the children's charity.

2. The first hypothesis, text-bullying will be associated with symptoms of depression, was examined by correlation and t-tests. A correlation between frequency of text-bullying and depressive symptoms revealed a positive relationship $(r=0.29, \mathrm{p}<.001)$ such that the more text-bullying reported, the more depressive symptoms were recorded. T-tests comparing students with $(\mathrm{N}=473)$ and without $(\mathrm{N}=651)$ text-bullying indicated that text-bullying victims reported significantly more depressive symptoms $(\mathrm{M}=1.13, \mathrm{SD}=0.57)$ than non-victims $(\mathrm{M}=0.85, \mathrm{SD}=0.51)$, $\mathrm{t}(1122)=8.726, \mathrm{p}<.001, \mathrm{~d}=0.52$.

3. To examine the assertion that text-bullying will be associated with more symptoms of depression than traditional bullying (Hypothesis 2), three categories were created to deal with the large overlap between text-bullying and traditional bullying. We found that $76 \%$ of text-bullying victims were also traditionally bullied. The three categories were: Text-Bullied Only $(\mathrm{N}=82)$, Traditional Bullied Only $(\mathrm{N}=365)$, and Both $(\mathrm{N}=360)$. ANOVA analyses indicated that while Text-Bullied Only (M $=.91, \mathrm{SD}=.49)$ and Traditional Bullied Only $(\mathrm{M}=.89, \mathrm{SD}=.51)$ did not differ significantly on depressive symptoms, their means were significantly lower than those in the Both category $(\mathrm{M}=1.17, \mathrm{SD}=.59)$, $\mathrm{F}(2,804)=26.483, \mathrm{p}<.001$.

\section{References}

Adair, V. A., Dixon, R. S., Moore, D. W., \& Sutherland, C. M. (2000). Ask your mother not to make yummy sandwiches: Bullying in New Zealand secondary schools. New Zealand Journal of Educational Studies, 35(2), 207-221.

Austin, S., \& Joseph, S. (1996). Assessment of bully/victim problems in 8 to 11 year-olds. British Journal of Educational Psychology, 66, 447-456.

Beran, T., \& Li, Q. (2005). Cyber-harassment: A study of a new method for an older behaviour. Journal of Educational Computing Research, $32(3), 265-277$.

Bond, L., Carlin, J. B., Thomas, L., Rubin, K., \& Patton, G. (2001). Does bullying cause emotional problems? A prospective study of young teenagers. British Medical Journal, 323(7311), 480-489.

Buhs, E. S., \& Ladd, G. W. (2001). Peer rejection as an antecedent of young children's school adjustment: An examination of mediating processes. Developmental Psychology, 57(4), 550-560.

Carroll-Lind, J., \& Kearney, A. (2004). Bullying: What do students say? Kairaranga, 5(2), 19-24.

Coleman, P. K., \& Byrd, C. P. (2003). Interpersonal correlates of peer victimization among young adolescents. Journal of Youth and Adolescence, 32(4), 301-314.

Cram, F., Doherty, L., \& Pocock, T. (1995). Bullying at school: Manukau North Special Education Service survey of schools. Unpublished report for Specialist Education Services, Auckland.

Crick, N. R., \& Nelson, D. A. (2002). Relational and physical victimization within friendships: Nobody told me there' $\mathrm{d}$ be friends like these. Journal of Abnormal Child Psychology, 30(6), 599-607.

Espelage, D. L., \& Swearer, S. M. (2003). Research on school bullying and victimization: What have we learned and were do we go from here? School Psychology Review, 32(3), 365-383.

Furlong, M. J., Sharma, B., \& Rhee, S. (2000). Defining school violence victim subtypes: A step toward adapting prevention and intervention programs to match student needs. In D. Singh \& C. B. Aspy (Eds.), Violence in American schools: A practical guide for counselors (pp. 67-88). Washington, DC: American Counseling Association. 
Grills, A. E., \& Ollendick, T. H. (2002). Peer victimization, global self-worth, and anxiety in middle school children. Journal of Clinical Child \& Adolescent Psychology, 31(1), 59-68.

Internet Safety Group. (2005). The text generation: Mobile phones and New Zealand youth. Auckland: Internet Safety Group.

Ladd, G. W., \& Kochenderfer, B. J. (1996). Peer victimization: Cause or consequence of school maladjustment. Child Development, 67, 1293-1305.

Maxwell, G., \& Carroll-Lind, J. (1997). The impact of bullying on children. Occasional Paper. Wellington: Office of the Commissioner for Children.

Ministry of Education. (2003). Reading literacy in New Zealand: Final results from the Progress in International Reading Literacy Study (PIRLS) and the repeat of the 1990-1991 Reading Literacy Study (10-year Trends Study) for year 5 students. Wellington: Ministry of Education.

Mullis, I. V. S., Martin, M. O., Gonzalez, E. J., \& Kennedy, A. M. (2003). PIRLS 2001 International Report: IEA's study of reading literacy achievement in primary school in 35 countries. Chestnut Hill, MA: International Study Center, Lynch School of Education, Boston College.

Nash, R. (2004). The association between social class and reading attainment; Is the most plausible explanation a "deficit theory"? Delta, 56(2), 83-95.

NCH. (2005). Putting $U$ in the Picture: Mobile bullying survey 2005. $<$ www.nch.org.uk>

Prochnow, J. E. (2004). The PIRLS 2001 study: What does it say about gender, learner literacy attitudes and behaviour in New Zealand. Delta, 56(2), 97-108.

Prochnow, J. E., \& Raskauskas, J. (2006). Examination of student experiences of bullying behaviours through the PIRLS international data set: National and international comparisons. Paper presented at the New Zealand Association for Research in Education Conference, Rotorua, New Zealand.

Olweus, D. (1993). Bullying at school: What we know we can do about it. Oxford: Blackwell.

Olweus, D. (2001). Peer harassment: A critical analysis and some important issues. In J. Juvonen \& S. Graham (Eds.), Peer harassment in school: The plight of the vulnerable and victimized (pp. 3-20). New York: Guilford Press.
O'Moore, M., \& Kirkham, C. (2001). Self-esteem and its relationship to bullying behavior. Aggressive Behavior, 27, 269-283.

Raskauskas, J., Carroll-Lind, J., \& Kearney, A. (2005). Text-bullying: Is it related to relational or verbal aggression? set: Research Information for Teachers, 3, 7-10.

Raskauskas, J., \& Stoltz, A. (2007). Involvement in traditional and electronic bullying among adolescents. Developmental Psychology, 43(3), 564-575.

Radloff, L. S. (1977). The CES-D scale: A self-report depression scale for research in the general population. Applied Psychological Measurement, 1, 385-401.

Schiano, D. J., Chen, C. P., Ginsberg, J., Gretarsdottir, U., Huddleston, M., \& Isaacs, E. (2002). Teen use of messaging media. Conference on Human Factors in Computing Systems. Retrieved January 8, 2007 from $<$ http://home.comcast.net/ $\sim$ diane.schiano/CHI2002.short.ttalk.pdf $>$

Smith, A., \& Williams, K. D. (2004). R U There? Ostracism by Cell Phone Text Messages. Group Dynamics: Theory, Research, and Practice, 8(4), 291-301.

Sullivan, K. (2000). Theanti-bullying handbook. Oxford: Oxford University Press.

Tunmer, W. E., \& Chapman, J. W. (2004). Why the reading achievement gap in New Zealand won't go away: Evidence from the PIRLS 2001 international study of reading achievement. New Zealand Journal of Educational Studies, 39(1), 127-145.

Whitney, I., \& Smith, P. K. (1993). A survey of the nature and extent of bullying in junior/middle and secondary schools. Educational Research, 35, 3-25.

\section{The authors}

Jane Prochnow is a Senior Lecturer in the School of Educational Studies, College of Education, Massey University. Her research interests include student behaviour difficulties and the associated impact on the development of children's literacy skills, teachers, classroom learning, and the school processes.

Juliana Raskauskas is a Lecturer in the School of Arts, Development and Health Education, College of Education, Massey University. Her research interests include bullying, risk/resilience factors for students, and adolescent development. 